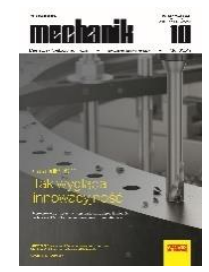

How to cite this article:

Authors: Wojciech Płowucha, Paweł Rosner, Mirosław Wojtyła

Title of article: „, Outsourcing in estimating the uncertainty of coordinate measurements”

Mechanik, No. 10 (2019)

DOI: https://doi.org/10.17814/mechanik.2019.10.82

\title{
Outsourcing in estimating the uncertainty of coordinate measurements
}

\author{
WOJCIECH PŁOWUCHA \\ PAWEŁ ROSNER \\ MIROSŁAW WOJTYŁA*
}

\author{
Dr inż. Wojciech Płowucha, wplowucha@ath.bielsko.pl, https://orcid.org/0000-0003-0446-9052 - Laboratorium Metrologii, Akademia \\ Techniczno-Humanistyczna w Bielsku-Białej, Bielsko-Biała, Polska \\ Mgr inż. Paweł Rosner, prosner@ath.bielsko.pl, https://orcid.org/0000-0003-4367-1384 - Laboratorium Metrologii, Akademia \\ Techniczno-Humanistyczna w Bielsku-Białej, Bielsko-Biała, Polska \\ Dr inż. Mirosław Wojtyła, mwojtyla@ath.bielsko.pl, https://orcid.org/0000-0002-6046-3870 - Laboratorium Metrologii, Akademia \\ Techniczno-Humanistyczna w Bielsku-Białej, Bielsko-Biała, Polska
}

The current situation in the estimation of uncertainty of coordinate measurements and the proposal to perform the uncertainty estimation service by an external institution are presented. This possibility arose thanks to the development of a method that uses the current calibration results as input information about the accuracy of the measuring machine, and as the information about the dimensions of the object - the coordinates of a small number of so-called characteristic points.

KEYWORDS: coordinate measuring technique, measurement uncertainty

\section{Introduction}

Knowledge of the uncertainty of measurements is currently required not only from calibration and research laboratories [1], but also from those performing measurements in industrial conditions [2]. On the other hand, it is well known that estimating the measurement uncertainty is quite a complex task, which has been clearly confirmed in several documents. For example, the publication [3] states: In principle, laboratories cannot be expected to undertake scientific work in order to evaluate the uncertainties related to their measurements and tests. In publication [4], one can read that estimating the measurement uncertainty is not an easy task - it requires specialist support.

Estimating the uncertainty of coordinate measurements [5-7] is particularly complex issue, and this measurement technique is widely used in the engineering industry. Although a lot of research is done on the uncertainty of coordinate measurements, there is no relatively cheap and easy-to-use software on the market. Research laboratories, and especially those operating in industry, using coordinate measuring systems, cannot spend too much time on the issue of measurement uncertainty. The paper presents an outsourcing proposal - providing a service for estimating the uncertainty of coordinate measurements at a distance.

\section{Current situation}

Standardization work on the uncertainty of coordinate measurements has been ongoing for a long time, but it focuses mainly on the needs of national metrology institutes (NMI) and calibration laboratories.

The ISO/TS 15530-1 [8] technical specification distinguishes between three methods for estimating the uncertainty:

- sensitivity analysis,

- use of calibrated workpieces or standards,

- use of computer simulation.

Standardization documents were prepared for two of these. The method using calibrated workpieces or standards has reached the International Standard [9]. The technical specification [10] was developed to the 
method using computer simulation, as well as other methods, in which computer calculations are used - UES (uncertainty evaluating software).

The International Standard [9] describes an experimental approach that formally allows for estimating the uncertainty of measurements of different geometrical characteristics (sizes, geometrical deviations). An important limitation of the broader application of this standard is that in order to carry out the procedure of measurement uncertainty evaluation, one needs a calibrated workpiece with a similar (and preferably identical) form to the object, for which the measurement uncertainty is to be evaluated. It results from the assumption adopted in the standard that the experiment is conducted in such a way that from time to time the calibrated workpiece will be measured instead of the measured object. Considering the fact that in industrial conditions the measured object is mounted in a special holder, and the measurement takes place in an automatic cycle and with optimal (from the point of view of measuring time) movement of the coordinate measuring machine (CMM), even slight differences in form and sizes of the calibrated workpiece prevent from its use. The practical use of this method in industrial conditions is limited to one case: when the calibrated workpiece is one of the manufactured items, previously calibrated on a more accurate CMM.

An approach similar to that described is quite often used by operators to ensure that CMM performs as designed. Operators keep for this occasion one of previously measured objects together with the measurement report and - in case of doubt as to the condition of the machine - they repeat the measurements of this object and compare the results obtained with the original report.

Contrary to its name, technical specification [10] does not provide any guidelines for the design of the simulation experiment. Its content includes requirements for suppliers of any (not only simulation) software for estimating uncertainty of coordinate measurements. Currently, software known under the name of Virtual Coordinate Measuring Machine (VCMM) [11] is offered on the European market, developed at PTB (Physikalisch-Technische Bundesanstalt), and on the American market - PUNDIT software [12].

\section{Sensitivity analysis method}

The Laboratory of Metrology of UBB developed an original method for estimating the uncertainty of coordinate measurements, which according to the classification given in document [8] is a method of sensitivity analysis, although due to the fact that software is available for the method, the document [10] also applies to it.

Individual characteristics (sizes and geometrical deviations) are modeled using a formula that expresses their value as a function of coordinate differences, the so-called characteristic points. These points can be simply interpreted as probing points using their minimum number. For each characteristic, for which the uncertainty of measurement is to be estimated, the coordinates of characteristic points of the workpiece must be provided, which can be points in any coordinate system, e.g. taken from a CAD model. Information about the accuracy of the coordinate measuring system is the standard uncertainty in length measurement, calculated on the basis of results of the last CMM calibration. All calculations are compiled in the form of an uncertainty budget. Details of the algorithm of the developed method are presented in publications $[5,6]$. Estimated values of the measurement uncertainty remain valid until the next CMM calibration.

\section{Development of calibration results}

In the first version of the developed method, information on CMM accuracy contained in the formula for the maximum permissible error (MPE) of length measurement was used. The authors' experience in the field of CMMs calibration shows that machines with the same MPE formula can differ significantly. Sometimes, the error diagram of length measurement of new machines takes up less than $1 / 3$ of the area defined by MPE, but there are also machines where this area is tightly filled (fig. 1a). Sometimes, asymmetrical filling of this area occurs (fig. $1 b$ ). For this reason, the latest version of the software also uses information about technical condition of CMM, contained in the results of the current calibration. The algorithm for developing calibration results is as follows. The CMM calibration results are $105 E_{i}$ errors for several different lengths. These errors are normalized to the range $(-1,1)$ using the formula:

$$
E_{\text {si }}=\frac{E_{i}}{M P E}
$$

Coefficient $\lambda$ to determine the standard uncertainty of length measurement is calculated as the moment from a sample of the order of 2 relative to zero (see [13] p. 1.14) according to the formula: 


$$
\lambda=\frac{1}{105} \sqrt{\sum_{i=1}^{105} E_{s i}^{2}}
$$

Due to the fact that the moment is calculated relative to zero (and not relative to the mean value, as in the case of using the standard deviation), the effect of randomization of systematic errors is achieved.

Sample histograms for normalized errors and calculated coefficients $\lambda$ are shown in fig. 2 (lower value of the coefficient means a worse condition of the machine compared to its MPE).

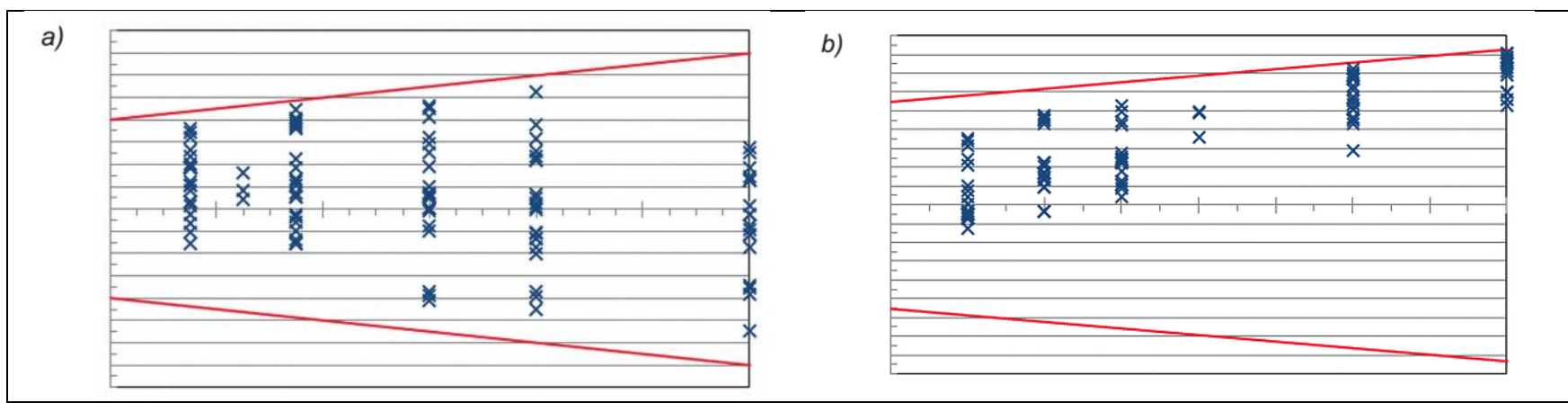

Fig. 1. Examples of CMM error diagrams: $a$ ) errors occupy the entire area of permissible errors, $b$ ) errors are arranged asymmetrically

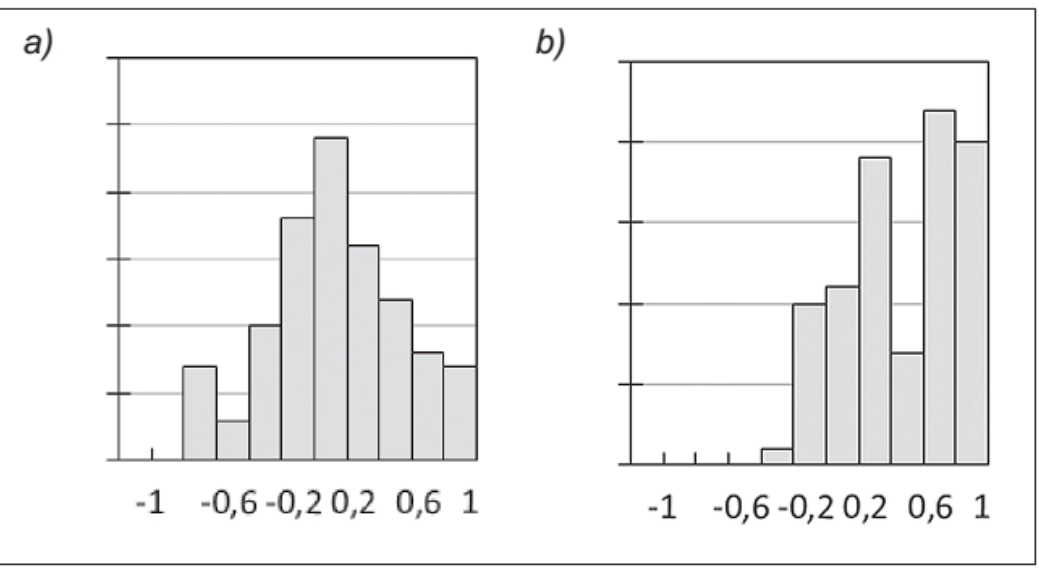

Fig. 2. Sample evaluation of calibration results for the needs of coordinate measurement uncertainty estimation software - histograms of indication errors normalized to $(-1,1)$; for the example in Fig. $1 a$ the coefficient $\lambda$ is 2.33 , and for the example in Fig. $1 b-1.70$

The standard uncertainty of length measurement, needed to calculate the measurement uncertainty of individual characteristics, is determined by the formula:

$$
u=\frac{M P E}{\lambda}
$$

\section{Estimation of measurement uncertainty at a distance}

The Laboratory of Metrology of UBB offers a service consisting in performing and documenting calculations of measurement uncertainty on the basis of the CMM calibration certificate and a technical drawing or CAD model with the characteristics marked, for which measurement uncertainty should be estimated.

Documentation of calculation consists of two parts. The first involves the development of calibration results needed to assess the probability distribution for the length measurement error, i.e. calculation of $\lambda$ coefficient. The second part contains uncertainty budgets for all indicated characteristics. The service is provided using electronic mail.

Fragments of two reports are cited below. The first concerns coaxiality (it is worth noting that the uncertainty of measuring this deviation depends significantly on the proportion of the distance of the toleranced feature from the datum and the length of the datum), and the second - the perpendicularity of axis 
to the plane. In both cases, the "point-to-straight line distance" model was used, but the unit vector in the model describing the orientation of the straight line is calculated differently.

It should be noted that characteristic points are points that belong to integral elements (surface of the object) or derivatives (axes), corresponding to the measurement strategy defined by mathematically minimum number of points.

Example 1. Results of estimation of uncertainty in coaxiality deviation measurement

Fig. 3 shows an example of information about the measured characteristics, needed to estimate the uncertainty. The uncertainty estimation results include the measurement model and the measurement uncertainty budget.

The coaxiality deviation $\Delta$ is equal to twice the value of the distance $l$ of point $S$ from straight line $A B$ (fig. 4):

$$
\Delta=2 l
$$

Distance of the $S$ point from the line $A B$ is given by the formula:

$$
l=\left|B S \times \frac{A B}{|A B|}\right|
$$

where: $A B=\left[a b_{1}, a b_{2}, a b_{3}\right], B S=\left[b s_{1}, b s_{2}, b s_{3}\right]$.

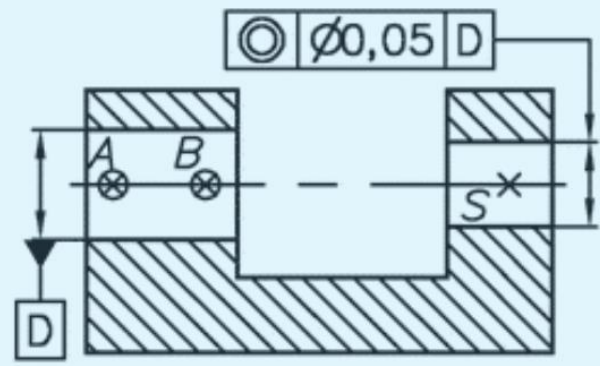

\section{Coordinates of characteristic points}

$A(-25,100,100), B(-5,100,100), S(95,100,100,01)$

Fig. 3. Information needed to estimate uncertainty of measurement of coaxiality deviation

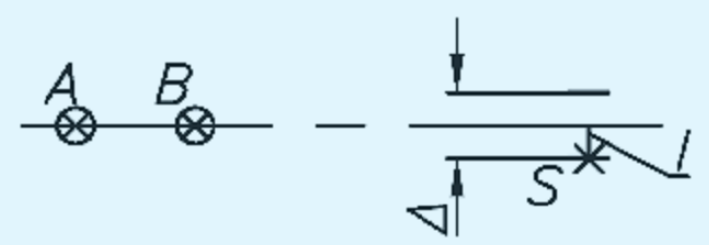

Fig. 4. Measurement model for coaxiality 
TABLE I. Uncertainty budget for coaxiality measurement for CMM for which $M P E= \pm(2+4 \mathrm{~L}) \mu \mathrm{m}$ and $\lambda$ $=2.33$

\begin{tabular}{|c|c|c|c|c|}
\hline Component & $x_{i}[\mathrm{~mm}]$ & $\frac{\partial l}{\partial x_{i}}$ & $u_{x i}=\frac{M P E}{\lambda}[\mu \mathrm{m}]$ & $\frac{\partial l}{\partial x_{i}} u_{x i}[\mu \mathrm{m}]$ \\
\hline$b s_{1}$ & 100 & 0 & 1.03 & 0 \\
\hline$b s_{2}$ & 0 & 0 & 0.86 & 0 \\
\hline$b s_{3}$ & 0,01 & 1 & 0.86 & 0.86 \\
\hline$a b_{1}$ & 20 & 0 & 0.89 & 0 \\
\hline$a b_{2}$ & 0 & 0 & 0.86 & 0 \\
\hline$a b_{3}$ & 0 & -5 & 0.86 & 4.29 \\
\hline & & & $u_{1}=$ & 4.38 \\
\cline { 3 - 5 } & & & $u_{\Delta}=$ & 8.8 \\
\cline { 3 - 5 } & & & $U_{\Delta}=$ & 17.6 \\
\hline
\end{tabular}

The appropriate uncertainty budget is given in tab. I.

For the case $\lambda=1.7$, the final calculation results are as follows: $u_{l}=6 \mu \mathrm{m}, u_{\Delta}=12 \mu \mathrm{m}, U_{\Delta}=24 \mu \mathrm{m}$.

In the uncertainty budget cited, only two of the potential components have non-zero values. The uncertainty budget contains information, on which components of distances between characteristic points actually have an effect on the measurement uncertainty of a given characteristic.

Example 2. Results of estimation of uncertainty of measurement of perpendicularity deviation

Fig. 5 shows an example of information about the measured characteristics, needed to estimate the uncertainty.

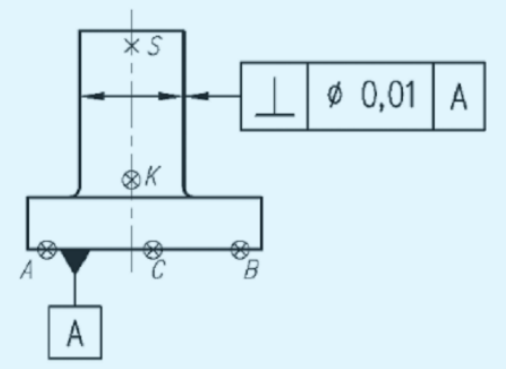

Coordinates of characteristic points $A(5,93,3,35), B(5,6,7,35), C(5,50,110), K(10,50,60)$, $S(205,50,60,01)$

Fig. 5. Information needed to estimate the measurement uncertainty of the perpendicularity of the axis in regard to the plane

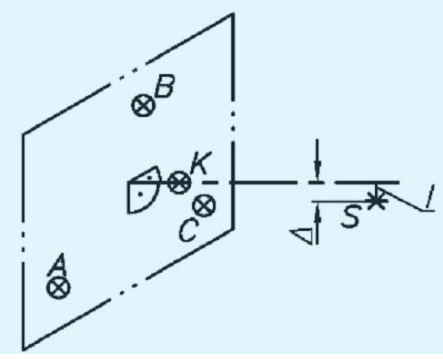

Fig. 6. Measurement model for the perpendicularity of the axis in regard to the plane 
The perpendicularity deviation $\Delta$ is equal to the value of the distance $l$ of the point $S$ from the straight line perpendicular to the plane $A B C$ and containing the point $K$ (fig. 6):

$$
\Delta=l
$$

Distance of the $S$ point from the straight line perpendicular to the $A B C$ plane and containing the $K$ point is given by:

$$
l=\left|K S \times \frac{C A \times C B}{|C A \times C B|}\right|
$$

where: $K S=\left[k s_{1}, k s_{2}, k s_{3}\right], C A=\left[c a_{1}, c a_{2}, c a_{3}\right], C B=\left[c b_{1}, c b_{2}, c b_{3}\right]$.

The uncertainty budget is given in tab. II.

TABLE II. Uncertainty budget for measurement of the perpendicularity for CMM, for which $M P E= \pm(2+$ 4L) $\mu \mathrm{m}$ and $\lambda=2.33$

\begin{tabular}{|c|c|c|c|c|}
\hline Component & $x_{i}[\mathrm{~mm}]$ & $\frac{\partial l}{\partial x_{i}}$ & $u_{x i}=\frac{M P E}{\lambda}[\mu \mathrm{m}]$ & $\frac{\partial l}{\partial x_{i}} u_{x i}[\mu \mathrm{m}]$ \\
\hline$k s_{1}$ & 195 & 0 & 1.19 & 0 \\
\hline$k s_{2}$ & 0 & 0 & 0.86 & 0 \\
\hline$k s_{3}$ & 0.01 & 1 & 0.86 & 0.86 \\
\hline$c a_{1}$ & 0 & -1.3 & 0.86 & 1.12 \\
\hline$c a_{2}$ & -43.3 & 0 & 0.93 & 0 \\
\hline$c a_{3}$ & 75 & 0 & 0.99 & 0 \\
\hline$c b_{1}$ & 0 & -1.3 & 0.86 & 1.12 \\
\hline$c b_{2}$ & 43.3 & 0 & 0.93 & 0 \\
\hline$c b_{3}$ & 75 & 0 & 0.99 & 0 \\
\hline & & & $u_{\Delta}=u_{l}=$ & 1.80 \\
\hline & & & $U_{\Delta}=$ & 3.6 \\
\hline
\end{tabular}

For the case $\lambda=1.7$, the final calculation results are as follows: $u_{l}=u_{\Delta}=2.5 \mu \mathrm{m}, U_{\Delta}=5 \mu \mathrm{m}$.

In the uncertainty budget cited, only two of the potential components have non-zero values. The budget contains information, on which components of distances between characteristic points actually have an impact on the measurement uncertainty of a given characteristic. Test results indicate that the uncertainties of measurements of different characteristics, carried out on the same CMM, can vary significantly. Particularly large uncertainty values occur when the tolerated element is off base.

Examples of coordinate measurement uncertainty estimation reports can be downloaded from the Laboratory of Metrology of UBBwebsite: www.lm.ath.bielsko.pl, "Download" tab.

\section{Validation of the results obtained}

The authors have at their disposal numerous tests confirming the correct operation of the developed software. In cases requiring validation, it is proposed to consider results obtained as a first step towards a conscious and responsible estimation of the coordinate measurement uncertainty. In order to make sure that the results obtained are correct, the authors propose to preserve one of the manufactured items and periodically repeat its measurements. After collecting 20 measurements, one can perform calculations of the 
approximate (due to the lack of a calibrated workpiece) value of the measurement uncertainty according to the methodology given in ISO 15530-3.

\section{Summary}

Presented proposal for outsourcing the estimation of measurement uncertainty (especially coordinate measurement) to external experts gives the opportunity to popularize estimation of measurement uncertainty in the broadly understood machine industry.

\section{REFERENCES}

[1] PN-EN ISO/IEC 17025:2018-02 Ogólne wymagania dotyczące kompetencji laboratoriów badawczych i wzorcujących.

[2] PN-EN ISO 10012:2004 Systemy zarządzania pomiarami. Wymagania dotyczące procesów pomiarowych i wyposażenia pomiarowego.

[3] EA-4/16 Wytyczne EA dotyczące wyrażania niepewności w badaniach ilościowych. European cooperation for Accreditation 2003.

[4] PKN-ISO/TR 10017:2005 Wytyczne dotyczące technik statystycznych odnoszących się do ISO 9001:2000.

[5] Płowucha W. „Szacowanie niepewności pomiarów współrzędnościowych metodą analizy wrażliwości - podstawy teoretyczne". Mechanik. 11 (2018): 953-956.

[6] Płowucha W. „Szacowanie niepewności pomiarów współrzędnościowych odchyłek równoległości osi metodą analizy wrażliwości". Mechanik. 12 (2018): 1136-1139.

[7] Gąska A. i in. „System prognozowania dokładności pomiaru z wykorzystaniem symulatora współrzędnościowej maszyny pomiarowej oraz jej wirtualnego modelu dokładności". Mechanik. 3 (2016): 220-221.

[8] ISO/TS 15530-1:2013 Geometrical product specifications (GPS). Coordinate measuring machines (CMM): Technique for determining the uncertainty of measurement. Part 1: Overview and metrological characteristics.

[9] PN-EN ISO 15530-3:2011 Specyfikacje geometrii wyrobów (GPS). Współrzędnościowe maszyny pomiarowe (CMM): Metoda wyznaczania niepewności pomiaru. Część 3: Zastosowanie przedmiotów wzorcowych i wzorców.

[10] ISO/TS 15530-4:2008 Geometrical Product Specifications (GPS). Coordinate measuring machines (CMM): Technique for determining the uncertainty of measurement. Part 4: Evaluating task-specific measurement uncertainty using simulation.

[11] Heisselmann D., Franke M., Rost K., Wendt K., Kistner T., Schwehn C. "Determination of measurement uncertainty by Monte Carlo simulation". Advanced Mathematical And Computational Tools In Metrology And Testing. XI, 2019.

[12] https://www.metrosage.com/punditcmm.html.

[13] PN-ISO 3534-1:2009 Statystyka. Słownik i symbole. Część 1: Ogólne terminy statystyczne i terminy wykorzystywane w rachunku prawdopodobieństwa. 